\title{
Literature Teaching in Brunei: Literature Textbook in Indonesian Language
}

\author{
Maslin Haji Jukim \\ \{muslin.jukim@ubd.edu.bn\} \\ Universitas Brunei Darusalam
}

\begin{abstract}
Formal education in Brunei Darussalam began in 1914 and has been developing from time to time to form the present day 21st Century Brunei Darussalam State Education System (SPN21). Considering how education in Brunei taught to respect the Malay language, it unconsciously and indirectly exposes the students to the teaching of Indonesian language through the literature teaching that uses books from Indonesia. In this discussion, the focus is on one of the Indonesian novel, namely Atheis by Achdiat Karta Mihardja, used as a textbook in high school for a long time. The use of Indonesian in the reading activity of this novel is quite understandable by teachers and students, but teaching and learning including examination is using Malay. Accordingly, Indonesian does not affect the language of communication in Brunei, instead it is still firmly uses the Brunei Malay Dialect and Standard Malay. Even so, the inclusion of Indonesian literary books, both creative and study books, illustrates the important role of Indonesian in providing an exposure to literature in Brunei as well as showing that Indonesian has become international.
\end{abstract}

Keywords: Brunei Education, Literature, Atheist Novel, Indonesian Language

\section{Pengajaran Sastra di Brunei: Buku Teks Sastra Dalam Bahasa Indonesia}

\begin{abstract}
Abstrak. Pendidikan formal di Brunei Darussalam bermula pada tahun 1914 dan berkembang dari masa ke masa sehingga terwujudnya Sistem Pendidikan Negara Brunei Darussalam Abad ke-21 (SPN21). Meninjau dari pendidikan di Brunei dalam memartabatkan bahasa Melayu, secara tidak sadar dan tidak langsung pelajar-pelajar terdedah pengajaran Bahasa Indonesia melalui pengajaran sastra yang banyak menggunakan buku-buku dari Indonesia. Dalam perbincangan ini menumpukan terhadap salah sebuah buku novel Indonesia, yaitu Atheis karya Achdiat Karta Mihardja, yang menjadi buku teks di sekolah menengah atas sejak lama. Penggunaan bahasa Indonesia dalam kegiatan membaca untuk novel ini cukup dapat dipahami oleh guru dan pelajar, tetapi pengajaran dan pembelajaran termasuk peperiksaan adalah menggunakan bahasa Melayu. Kemudian, bahasa Indonesia tidak memengaruhi bahasa komunikasi di Brunei yang masih tegar dengan bahasa Dialek Melayu Brunei dan bahasa Melayu Standar. Sungguhpun begitu, kemasukan buku-buku sastra dalam bahasa Indonesia, baik kreatif dan kajian, menggambarkan peranan penting bahasa Indonesia dalam memberikan pendedahan tentang sastra di Brunei sekaligus memperlihatkan bahasa Indonesia itu sudah terinternasionalkan.
\end{abstract}

Kata kunci: Pendidikan Brunei, Sastera, Novel Atheis, Bahasa Indonesia 


\section{Pendahuluan}

Bahasa Indonesia itu diajarkan dalam pendidikan di Brunei. Pengajaran ini tidak secara langsung. Pengajaran sastera di Brunei buat beberapa dekad telah menggunakan novel Atheis (1949) karya Achdiat Karta Mihardja yang dijadikan buku teks sastera di peringkat sekolah menengah atas (Pusat Tingkatan Enam). Tanpa ada terjemahan dalam bahasa Melayu novel Atheis ini diajarkan. Namun, persoalan Bahasa Indonesia tidak menjadi isu (atau jika ada pun bukan menjadi isu utama). Hal yang mewujudkan kebimbangan hanya isu ideologi yang terkandung dalam novel Atheis. Judulnya saja sudah membuat orang bimbang dan ragu. Sunggupun begitu, novel Atheis ini tetap juga bertahan sejak awal 1970an sehingga tahun awal 2000an (kira-kira pada tahun 2014). Kemudian barulah diganti dengan novel tempatan Hadiah Sebuah Impian (1983) karya Muslim Burmat, penulis tempatan. Selama beberapa dekad itu secara langsung para pelajar Brunei telah didedahkan pemikiran dan budaya yang terdapat dalam novel Atheis itu dalam Bahasa Indonesia. Justeru, melalui Bahsa Indonesia yang digunakan dalam novel Atheis ini berposisi sebagai alat komunikasi untuk menyampaikan aspek intrinsik dan ekstrinsik novel tersebut. Hakikatnya, Bahasa Indonesia itu di Brunei berlegar dalam buku-buku teks bukan sahaja novel Atheis dan Keluarga Gerilya (1950) karya Pramoedaya Antatoer malah buku-buku teks sejarah perkembangan sastera umpamanya Puisi Lama (1941) karya Sutan Takdir Alisjahbana Kesusasteraan Lama Indonesia (1954) karya Zuber Usman, dan beberapa karya HB Jassin. Tidak kurang juga adanya novel-novel Indonesia yang sampai kepada pembaca di sini umpamanya novel-novel karya Hamka. Secara tidak langsung, Bahasa Indonesia itu menggambarkan sudah mendunia (internasional) dan maju.

\section{Hasil dan Pembahasan}

\section{Senario Pendidikan di Brunei}

Sebagai sebuah negara yang memiliki bahasanya, setentunya menginginkan bahasa itu bertahan. Bertahan dalam erti digunakan sesuai sebagai lambang jati diri seperti umgkapan 'Bahasa Jiwa Bangsa'. Inilah yang juga dihasratkan Negara Brunei Dasrussalam sebagai salah satu agenda penting dalam pendidikan. Justeru, Bahasa Melayu diperjuangkan sebagai bahasa pengantar dalam menyampaikan ilmu sehingga Bahasa Melayu dimaktubkan dalam Perlembagaan Negeri Brunei 1959 yang dinyatakan Bahasa Melayu sebagai bahasa rasmi negara. Walau bagaimanapun, sitiuasi dalam memperjuangkan kedaulatan Bahasa Melayu ini dalam pendidikan di Brunei berhadapan dengan liku-liku cabaran dan hambatan. Oleh yang demikian, Dasar-dasar pendidikan di Brunei dibentuk dan bersilih ganti dengan pembaharuan dan pembaikan bermula pada tahun 1954, 1962, 1972, 1984 sehingga Sistem Pendidikan Negara Brunei Abad 21 (SPN21).

Sekitar 1960an beberapa gangguan berlaku dalam politik di Brunei. Ketika itu, berbagaibagai isu hal dalaman dan hubungan luar negara terutama negara jiran perlu ditangani kerajaan Brunei. Isu-isu ini memberi kesan kepada perkembangan dan kemajuan pendidikan Brunei. Peristiwa pada tahun 1962 iaitu peristiwa pemberontakan di Brunei membawa kesan terhadap hubungan dengan Indonesia. Kemudian, desakan Malaysia yang menginginkan negara-negara di Borneo iaitu Sabah, Sarawak dan Brunei masuk bergabung dengan Malaysia. Apabila kerajaan menolak cadangan ini dan Brunei keluar dari gabungan Malaysia itu menimbulkan kemarahan pemimpin Malaysia ketika itu dan beberapa tindakan dilakukan terhadap Brunei 
umpamanya penarikan balik pegawai-pegawai warga Malaysia yang diperbantukan di Brunei ditarik balik dan ini termasuklah guru-guru Malaysia. Ini terkesan apabila melibatkan guruguru yang mengajar Bahasa Melayu dan natijahnya juga kesukaran mendatangkan buku-buku teks dari Malaysia untuk membantu pendidikan Bahasa Melayu di Brunei. Brunei betul-betul kekurangan tenaga pengajar, pentadbir dan buku-buku teks sekolah. Situasi ini cuba dialihkan bantuan ke Indonesia. Namun, halangan dalam berlakunya perbezaan bahasa kerana terdapatnya kosa kata yang berbeza dan tidak difahami di Brunei. Selain itu, kesan dari peristiwa 1962 juga menjadikan Brunei tidak begitu cenderung untuk mendatangkan tenaga pengajar dari Indonesia.

\section{Bahasa Melayu Sebagai Bahasa Pengantar Dalam Pendidikan}

Setelah peperangan Dunia II tamat dan pemerintahan Tentera Jepun di Brunei berakhir, salah satu agenda pembangunan semula negeri Brunei ialah pendidikan. Pendidikan di Brunei terganggu bukan saja dari aspek pengajarannya yang mengikut kehendak tentera Jepun tetapi selepas berakhirnya pemerintahan tentetara Jepun bangunan sekolah ada yang roboh sewaktu kedatangan tentera berikat. Pentadbiran British kembali berada di Brunei dan membaik pulih insfrustruktur dan pendidikan di Brunei. Sekolah-sekolah dibuka semula. Pada kali ini, semangat nasionalisme orang Brunei berkobar kesan dari beberapa buah negara sudah dapat kebebasan kemerdekaan. Justeru, dalam agenda semangat nasionalisme ini Bahasa Melayu diperjuangkan terutama di dalam pendidikan. Bahasa Melayu perlu diangkat sebagai bahasa pengantar atau utama dipergunakan dalam pengajaran dan pembelajaran di sekolah-sekolah. Oleh yang demikian, terwujudnya dasar-dasar pendidikan.

\section{Buku-buku Teks Bahasa Indonesia}

Novel Atheis karya pertama kali diterbitkan pada tahun 1949. Penerbitan novel ini ketika Brunei belum lama terlepas dari belenggu peperangan Dunia II iaitu pemerintahan tentera Jepun. Brunei diperintah oleh tentera Jepun dari tahun 1941 sehingga 1945. Banyak negara yang mendapat kemerdekaan dari peluang yang ada ketika itu seperti Indonesia (1945), India (1947), dan Malaysia (1957), tampias semangat nasionalisme sampai juga ke Brunei dan Bahasa Melayu tekal menjadi agenda utama dalam pendidikan. Dalam usaha memperjuangkan Bahasa Melayu untuk dijadikan bahasa utama yang dipergunakan dalam pendidikan, Brunei berhadapan dengan 'krisis' bersama negara jiran sehingga mengakibatkan kekacaun dalam negeri. Sungguhpun hubungan Brunei dan Indonesia kurang mesra, anehnya buku-buku dari Indonesia dijadikan buku-buku teks sastera dalam pengajaran dan pembelajaran bahasa dan sastera. Novel Atheis karya Achdiat Mihardja dan novel Keluarga Gerilya karya Pramoedya Antatoer dijadikan buku teks sastera. Selain itu buku-buku sejarah dan perkembangan sastera termasuk genre karya puisi tidak terlepas menjadi buku teks atau sekurang-kurangnya buku rujukan dalam pendidikan sastera di peringkat menengah.

\section{Novel Atheis}

Novel Atheis dijadikan teks pengajaran dan pembelajaran di peringkat menengah atas iaitu tingkatan enam yang akan menduduki peperiksaan General Certificate of Education ' $A$ ' Level (GCE 'A' Level). Novel ini digunapakai dalam pengajaran dan pembelajaran sastera sehingga tahun 2013. Kemudian pada tahun 2014 diganti dengan novel Hadiah Sebuah Impian karya penulis tempatan, Muslim Burmat. Sungguhpun novel Atheis dalam bahasa Indonesia, namun guru-guru sastera yang mengajar novel ini menggunakan penyampaian pengajarannya dalam Bahasa Melayu. Di samping itu, agak menghairankan juga novel Atheis ini dijadikan buku teks dalam masa hubungan Negara Brunei dan Indonesia berbaik semula. Novel Atheis 
ini mengandungi umumnya tentang kegoncangan kepercayaan. Pengkisahan novel ini tertumpu kepada watak Hasan sebagai seorang yang alim dan kuat beribadah dari keturunan keluarga yang soleh dan taat menjalankan ajaran agama Islam dan dipertentangkan dengan watak Anwar seorang Anarkis. Kemudian, di tengah-tengah pertentangan kedua-dua watak adalah watak Kartini yang memberi kegoncangan jiwa dan kehidupan Hasan. Di bawah ini dipetik sinopsis cerita dalam novel Atheis:

Novel ini menceritakan kisah hidup Hasan, anak Raden Wiradikarta, pensiunan mantri guru, yang tinggal di kampung Panyeredan, Garut. Keluarga Raden Wiradikarta adalah keluarga yang saleh dan taat menjalankan ajaran agama Islam penganut tarikat. Sejak kecil Hasan sudah mendapat didikan agama secara mendalam. Ia tumbuh menjadi anak yang patuh kepada orang tua dan taat menjalankan ajaran agama. Cerita tentang surga dan neraka sering didengarnya selagi ia kecil, baik dari ibu maupun dari pembantunya. Setelah dewasa, Hasan mengikuti jejak orang tuanya berguru ke Banten untuk memperdalam ajaran mistik. Hasan melakukan beberapa syarat dalam ajaran itu, misalnya mandi 40 kali dalam satu malam. Akhirnya, Hasan terkena penyakit TBC. Karena taatnya dalam menjalankan ajaran agama, di kalangan teman-temannya sekantor (di Kotapraja Bandung), ia dijuluki sebagai kiyai. Tanpa diduga, Rusli (teman Hasan waktu kecil) dan Kartini datang ke kantor Hasan. Pertemuan itu sangat penting bagi Hasan. Dalam pandangannya, Kartini mirip sekali dengan Rukmini, pacarnya dulu. Di samping itu, Hasan memandang Rusli dan Kartini terlalu bebas dan modern. Hasan bertekad mengislamkan kedua orang itu yang dipandangnya telah murtad. Namun, Hasan tidak mampu berbuat apa-apa, malah sebaliknya terjerat oleh pokok-pokok pikiran Rusli yang selalu memberikan sanggahan terhadap keyakinan agamanya dengan retorika marxisme. Ia mulai aktif membaca literatur marxisme. Di samping itu, Hasan mulai ikut dalam berbagai kegiatan partai yang diadakan oleh Rusli dan kawan-kawannya. Hubungan Hasan dengan Kartini dan Rusli makin akrab. Keimanan Hasan yang semula kuat mulai rapuh. Di sisi lain, muncul pula Anwar yang menganggap Tuhan itu madat. Anwar juga menaruh hati kepada Kartini. Kartini pun sering bersikap membuat Hasan cemburu. Untuk itu, Hasan lebih aktif lagi untuk menarik perhatian Kartini. Hasan pulang ke kampung halamannya dan Anwar ikut serta. Saat itu terjadilah pertentangan paham antara Hasan dan orang tuanya tentang masalah agama dan ihwal memilih pasangan hidup. Ia kembali ke Bandung. Sesampainya di sana, Hasan tetap nekat menikah dengan Kartini. Waktu terus berlalu, kehidupan rumah tangga Hasan dan Kartini mulai berubah. Hasan mulai tidak percaya terhadap cinta Kartini. Di sisi lain, Hasan selalu teringat akan pertengkaran dengan ayahnya, apalagi setelah ayahnya itu meninggal tanpa memaafkannya. Pertengkaran demi pertengkaran antara Hasan dan Kartini pun terus berlangsung hingga rumah tangga itu menjadi retak. Karena bertengkar, Kartini meninggalkan rumah, ia pergi tanpa tujuan. Akhirnya, ia bertemu dengan Anwar. Berkat rayuan Anwar, mereka tidur di penginapan. Anwar ingin melampiaskan nafsunya. Kartini lari meninggalkan penginapan tersebut. Hasan kembali teringat kepada Tuhan dan ia menyesali kekeliruannya selama ini. Ia telah kehilangan orang-orang yang dicintainya. Hasan baru pulang dari kampung. Saat itu Bandung dikuasai oleh Jepang dan Jepang sedang mengadakan patroli. Banyak orang berlindung di lubang perlindungan begitu pula Hasan. Sesudah merasa keadaan aman, Hasan keluar dari lubang perlindungan. Sementara itu, penyakit TBC Hasan bertambah parah. Hasan tidak mungkin lagi melanjutkan perjalanan ke tempat tinggalnya sehingga memutuskan untuk mencari penginapan yang terdekat. Di 
penginapan itu Hasan menemukan daftar nama Anwar dan Kartini. Hal itu menunjukkan bahwa mereka pernah tidur di situ. Setelah Hasan mendapat penjelasan dari pelayan penginapan itu, dengan emosional ia ingin membalas kelakuan Anwar dan Kartini. Oleh karena itu, Hasan nekad mencari Anwar tanpa memperhatikan keadaan sekitarnya. Karena disangka mata-mata musuh, Hasan ditembak oleh Jepang dan akhirnya meninggal dunia. Dengan meninggalnya Hasan, Kartini pun putus asa. Kartini merasa berdosa kepada Hasan dan ia tidak tahu bagaimana cara menebus dosanya itu.

\section{Keseuaian Novel Atheis dalam Pendidikan Di Brunei}

Berdasarkan pengkisahan novel Atheis ini, adalah wajar kebimbangan timbul di kalangan orang Brunei. Kebimbangan itu kadang membawa kepada kesimpulan untuk mendudukkan novel Atheis ini 'diharamkan' untuk dibaca tetapi ini tidak berlaku malah menjadi buku teks yang mampu bertahan selama beberapa dekad dalam pendidikan sastera di Brunei. Pergolakan jiwa watak Hasan dalam novel Atheis terletak pada dua aspek iaitu kegoncangan kepercayaan beragama dan percintaan. Melihat pada aspek kegoncangan kepercayaan sahaja setentunya membuka ruang untuk memberi kesimpulan tidak wajar untuk dibaca apatah lagi untuk diajarkan di sekolah. Pengaruh peristiwa dan aksi dalam novel Atheis ini yang begitu berisiko tinggi kepada anak-anak muda Brunei. Ini persoalan pegangan atau kepercayaan tentang agama Islam oleh kerana itu terdapat suara-suara yang berpendapat novel ini boleh menggugat akidah Islam orang Brunei.

Kemudian, kisah percintaan yang berlaku dalam novel ini kadang memberi ketegangan tentang kebimbingan pembaca terhadap soal kepercayaan tetapi memberi kesan juga melonggarkan keadaan yang tegang dengan fitrah dunia percintaan. Kedua-dua aspek ini mempunyai magnetic sendiri untuk mengimbangi keadaan dalam menerima dan mengikuti kisah novel Atehis ini.

Secara positif, peristiwa dan aksi yang berlaku dalam novel Atheis ini memberi ruang pemikiran untuk menerimanya sebagai sesuatu yang perlu dijadikan iktibar sesuai dengan fungsi karya sastera makanya novel ini memberikan falsafahnya yang baik jadi teladan yang buruk jadi sempadan. Oleh itu, signifikan mempelajari novel Atheis ini lebih dominan dan jelas. Novel ini memperlihatkan atau memberi gambaran kepaada masyarakat Brunei tentang pegangan beragama Islam itu bukan semata-mata suatu warisan turun temurun tetapi kewajaran peneguhan tentang keesaan dan kewujudan Tuhan iaitu persoalan keimanan. Goncang dan rosak agama Islam jika kepercayaan ini hanya melekat di badan sebagai pakaian sahaja. Ini perlu diketahui dan ditanamkan kepada anak-anak muda tentang kepercayaan beragama terutama agama Islam. Bercontoh dengan watak Hasan seorang yang memiliki nilainilai kebaikan yang perlu dicontohi. Hasan merupakan seorang pemuda yang rajin melaksanakan ibadah solat dan tidak luput untuk mengerjakannya. Namun, pada masa yang sama diperingatkan juga setinggi mana pun keimanan seseorang akan tidak terlepas dari gangguan dan hambatan yang memesongkan keyakinan beragama. Dalam novel Atheis ini memang didominasi oleh hal keagamaan tentang kepercayaan sehingga membawa kesankesan tertentu bagi setiap watak. Akan tetapi, nilai-nilai kebaikan yang lain memang ada terkandung dalam novel ini umpamanya tentang ketaatan, kejujuran, toleransi, sosialisasi dan sebagainya. Di sinilah kekuatan dan signifikan untuk menafikan tanggapan-tanggapan terhadap novel Atheis ini berisiko mempengaruhi keyakinan anak-anak muda tentang agama Islam.

Sungguhpun begitu, novel Atheis ini tidak sesuai diajarkan di peringkat menengah bawah. Ini wajar untuk merasa bimbang kerana peringkat menengah bawah belum mampu untuk 
berfikir tentang hal-hal sedemikian. Justeru, novel Atheis ini hanya sesuai diajarkan di peringkat menengah atas iaitu tingkatan enam kerana mereka ini dianggap sudah mampu berfikir lebih jauh. Mereka ini dianggap dapat melihat tentang hal-hal yang merosakkan kepercayaan dan dapat menghindari berfikiran secara bebas dan terkawal.

\section{Bahasa Indonesia}

Istimewanya, novel Atheis yang digunakan sebagai buku teks dalam pendidikan sastera di Brunei adalah dalam bahasa Indonesia. Beberapa dekad pelajar-pelajar Brunei yang mengikuti pelajaran sastera di tingkatan enam membaca novel ini dalam bahasa Indonesia. Tidak pernah berlaku suara yang mengeluh umpamanya kesukaran dalam memahami novel Atheis ini malah diperiksakan sebagai salah satu soalan yang terkandung dalam peperiksaan GCE 'A' Level dalam mata pelajaran Bahasa Melayu II keran ketika itu mata pelajaran Bahasa Melayu ada dua kertas, kertas I tentang Bahasa Melayu dan Kertas II tentang sastera.

Soalan peperiksaan tersebut dalam Bahasa Melayu dan dijawab juga dalam Bahasa Melayu. Anehnya, pelajar-pelajar mampu untuk mejawab sedangkan memerlukan kefahaman tentang novel Atheis yang dalam bahasa Indonesia. Ini membawa makna bahasa Indonesia difahami oleh orang Brunei yang diwakili oleh pelajar-pelajar dan yang menakjubkan juga kandungan novel ini dianggap berat yang menyentuh tentang keyakinan akidah. Dalam kefahaman isu yang berlaku dalam novel Atheis ini sebenarnya dibantu sendiri oleh bahasa Indonesia sendiri tanpa menolak juga peranan guru-guru yang mengajar bukan daripada kalangan Indonesia. Guru-guru ini dari Malaysia dan tempatan yang menggunakan Bahasa Melayu.

Bentuk soalannya pula pada kebiasaanya tentang dialog. Soalan meminta penjelasan apa yang berlaku sebelum atau selepas dialog tertentu diungkapkan. Sememangnya dialog tersebut dalam bahasa Indonesia yang dipetik dari novel Atheis. Kalau tidak memahami kandungan dialog tersebut mungkin saja sukar untuk menjawab permintaan soalan peperiksaan. Secara tidak langsung, bahasa Indonesia yang digunakan dalam novel Atheis tidak menghalangi pengajaran dan pembelajaran sastera di peringkat menengah enam malah pengetahuan bahasa Indonesia tidak diperlukan.

\section{Pengalaman Penghujung Tahun 1980an}

Novel Atheis dijadikan buku teks sastera di Brunei sehingga tahun 2013. Buku teks ini hanya digunakan dan sesuai untuk mereka yang berada di tingkatan menengah enam. Pada tahun 1970an dan pertengahan 1980an sekolah yang tertinggi pada ketika itu hanya sekolah menengah enam iaitu menengah enam bawah dan menengah enam atas. Sekolah ini hanya satu-satunya menampung para pelajar yang belajar di peringkat menengah enam atas yang disebut Pusat Tingkatan Enam, Gadong. Nnovel Atheis memang terdapat suara-suara yang memberi amaran untuk berhati-hati membaca novel tersebut. Di sebaliknya, terdapat juga yang seronok membaca dan mempelajari novel Atheis sehingga membawa perbincangan yang hangat.

Perbicaraan ini berdasarkan pengalaman peribadi yang pernah menuntut di Pusat Tingkatan Enam atau Maktab Duli Pengiran Muda ai Muhtadee Billah. Waktu itu tahun 19881989. Pada awalnya, memang merasa bimbang juga tentang suara-suara senior yang menceritakan tentang kesan-kesan setelah membaca novel Atheis. Paling menakutkan apabila ada khabar angin yang dinyatakan ada sampai pelajar yang keluar dari agama Islam setelah membaca dan berbincang mengenai kandungan novel Atheis.

Cerita-cerita yang tersebar tersebut sebenarnya tidak seindah rupa. Mempelajari, membaca, memahami dan membincangkan novel Atheis ketika itu membantu perkembangan 
minda dan berani untuk berhujah. Perbincangan terhadap kandungan novel Atheis ini 'hangat' kerana masing-masing mempunyai sisi pandangan masing-masing. Anehnya, persoalan yang dibimbangkan tentang kepengaruhan cerita dari novel Atheis ini membawa sesat adalah tidak berlaku dan tida benar. Dalam peperiksaan ketika itu, soalan tentang novel Atheis jadi pilihan jawapan.

\section{Simpulan}

Bahasa Indonesia dalam pendidikan di Brunei suatu ketika pernah diajarkan secara tidak langsung. Hal ini berlaku di antara sedar dan tidak sedar kerana melalui mata pelajaran sastera. Di sebalik liku-liku memperjuangkan Bahasa Melayu sebagai bahasa pengantar dalam pendidikan di Brunei dan berlakunya pergeseran hubungan negara-negara jiran di sekitar tahun 1960an, buku-buku teks dalam pengajaran sastera kebanyakannya dari Indonesia. Ini bermakna buku-buku teks tersebut membawa Bahasa Indonesia ke Brunei melalaui pendidikan. Sungguhpun begitu, dengan bercontohkan novel Atheis yang bertahan beberapa dekad sebagai buku teks novel dalam pengajaran sastera tidak mempengaruhi para pelajar dari aspek kandungan yang dibimbangkan selama ini dan juga kepengaruhan Bahasa Indonesia dalam komunikasi seharian di kalangan para pelajar. Buku teks novel Atheis dalam Bahasa Indonesia tetapi tenaga pengajarnya menyampaikannya dalam Bahasa Melayu malah dalam perbincangan dan peperiksaan adalah dalam Bahasa Melayu. Ini memberikan keunikan yang berlaku dalam senario pengajaran sastera di Brunei yang menggunakan novel Atheis umpamanya yang perlu dibaca dan difahami melalai Bahasa Indonesia. Pada masa yang sama, ini memperlihatkan juga bahawa Bahasa Indonesia itu terangkat diperingkat internasional.

\section{Referensi}

[1] Asbol Bin Hai Mail, Haji. 2000. Sejarah Perkembangan Pendidikan di Brunei 1950-1985. Bandar Seri Begawan: Pusat Sejarah Brunei

[2] Haryo Seto Saktiyono, Herman J Waluyo, Sri Hastuti. "Novel Atheis Karya Achdiat Karta Mihardja sebagai Materi Pembelajaran Sastra: Analisis Psikologi Sastra dan Nilai Pendidikan". Jurnal.uns.ac.id/Basastra/article/view/37710. (20//1/21).

[3] Hildan Udayana dan Bambang Indiatmotko. "EKspresi Cinta dan Citra Religius dalam Novel Atheis Karya Achdiat Kartamihardja”. Seloka 6(2) (2017). http://journal.unnes.ac.id/sju/index.php/seloka (20/1/21).

[4] Ensiklopedia Sastra Indonesia - Badan Pengembangan dan Pembinaan Bahasa, Kementerian Pendidikan dan Kebudayaan Republik Indonesia http://ensiklopedia.kemdikbud.go.id/sastra/artikel/Atheis (20/1/21) 